ARTIKEL PENELITIAN

\title{
TRACER STUDY FK UNAND 2008 : PERSEPSI ALUMNI TERHADAP PELAKSANAAN PENDIDIKAN KEDOKTERAN DI FAKULTAS KEDOKTERAN UNIVERSITAS ANDALAS
}

\author{
Yulistini $^{1}$, Aisyah Elliyanti ${ }^{1}$, Nora Harminarti ${ }^{2}$, Taufik Ashal ${ }^{3}$, Ilmiati ${ }^{4}$ \\ 1. Staf pengajar bagian pendidikan kedokteran fk unand \\ 2. Staf pengajar bagian parasitologi fk unand \\ 3. Staf pengajar bagian ilmu kedokteran jiwa fk unand \\ 4. Staf pengajar bagian farmakologi fk Unand \\ E-mail : yulistinimd_padang@yahoo.co.id
}

\begin{abstract}
Abstrak
Tracer Study adalah penelitian yang menghimpun informasi tentang sebaran para alumni dan berbagai masukan yang dapat membantu pengembangan kurikulum dan proses pembelajaran di Fakultas Kedokteran Universitas Andalas (FK Unand).

Penelitian tracer study di FK Unand 2008 menggunakan pendekatan kuantitatif dengan metode deskriptif analitik. Respondennya adalah alumni FK Unand yang dipilih secara purposive random sampling, yaitu berdasarkan keikutsertaan kegiatan ilmiah dan kegiatan lainnya di FK Unand tahun 2008.

Hasil penelitian menunjukkan persentase responden yang puas dan tidak puas terhadap pelayanan akademik sebanyak 55,5\% dan 45,5\% dari 124 responden. $61,9 \%$ responden merasa puas terhadap pendidikan preklinik dan 50,4\% merasa puas terhadap pendidikan klinik. Untuk penilaian kompetensi berdasarkan persepsi responden menunjukkan 66,7\% merasa kompeten saat menyelesaikan pendidikan. Uji bivariant menunjukkan hubungan bermakna antara kepuasan terhadap pendidikan preklinik dan klinik, tahun masuk dan jenis kelamin terhadap kompetensi $(\mathrm{p}<0.05)$.

Kesimpulan adalah sebagian besar responden merasa puas terhadap pelayanan akademik dan pendidikan preklinik. Persentase ketidakpuasan terhadap pendidikan klinik hanya sedikit lebih tinggi dari pada yang puas. Terdapat hubungan yang bermakna antara kepuasan terhadap pendidikan preklinik, klinik, tahun masuk, dan gender terhadap persepsi responden terhadap kompetensi mereka.

Kata kunci :tracer study, alumni, tahun masuk, pre klinik, klinik, kompetensi
\end{abstract}

\section{Abstract}

Tracer Study is a research that gather information about the distribution of the alumni and the various inputs that may help the development of curriculum and learning process in the Faculty of medicine Andalas University (FK Unand) Tracer studies FK Unand 2008 using a quantitative approach with a descriptive 
analytical method. Respondents are FK Unand's graduates that selected by purposively random sampling, who followed FK Unand's scientific activities and other during 2008.

The results show the percentage of respondents who are satisfied and not satisfied with the academic services as much as $55.5 \%$ and $45.5 \%$ of 124 respondents. $61.9 \%$ of respondents were satisfied with preclinical education and $50.4 \%$ were satisfied with educational clinics. For the respondents' perceptions of their competence indicated the majority $(66.7 \%)$ felt competent at completing education. Bivariant test showed a significant relationship between satisfaction in preclinical and clinical stage, years in and to their competency $(\mathrm{p}<0.05)$.

The conclusion are most respondents were satisfied with the academic services and preclinical stage. The percentage of dissatisfaction with clinic stage just slightly higher than who satisfied. There is a significant association between satisfaction with preclinical and clinical stage, year in, and gender to respondent's perception of their competence.

Key word : tracer study, alumni, year-in, pre-clinical, clinical, competence 


\section{Pendahuluan}

Dunia pendidikan termasuk pendidikan kedokteran selalu dinamis. Perubahan zaman dan era globalisasi menuntut suatu perguruan tinggi agar menghasilkan lulusan dengan kompetensi yang sesuai kebutuhan. ${ }^{(1,2)}$ Peningkatan kualitas pendidikan yang konsisten dan berkelanjutan untuk menghasilkan dokter yang berkualitas sesuai dengan standar kompetensi pendidikan dokter Indonesia dan mampu bersaing secara global merupakan bagian dari visi dan misi Fakultas Kedokteran Universitas Andalas FK UNAND yang tercantum didalam (Renstra) rencana strategis FK UNAND 2007-2011. ${ }^{(3)}$

Salah satu upaya dalam meningkatkan kualitas pendidikan adalah institusi pendidikan dalam hal ini Fakultas Kedokteran dituntut untuk terus melakukan perbaikan kurikulum dan proses pembelajaran. Selain itu juga didukung dengan peningkatan kualitas dan kuantitas staf akademik serta fasilitas dan sarana penunjang. Pemerintah juga mengeluarkan Peraturan dan UndangUndang yang ikut mempengaruhi proses pendidikan dokter yaitu UU No.29 th 2003 tentang Praktek Ked, UU No.32 th 1996 tentang tenaga kesehatan, dan UU perlindungan konsumen. ${ }^{(3,4)}$ berdasarkan hal tersebut, tuntutan untuk institusi pendidikan dokter tidak hanya untuk menghasilkan seorang dokter baik dari segi pengetahuan, namun juga melatih softskills mereka. Maraknya tuntutan malpraktek dimasyarakat saat ini baik dalam bentuk kurangnya pengetahuan seorang dokter atau kelalaian, membuat institusi pendidikan dokter harus merumuskan dengan cermat dengan berpedoman pada kompetensi dokter Indonesia pengetahuan dan keterampilan yang dibutuhkan oleh seorang dokter dalam menjalankan profesi kedokteran. ${ }^{(4)}$

Tracer Study adalah salah satu kegiatan penelitian yang menghimpun informasi tentang sebaran para alumni dan berbagai masukan yang dapat membantu pengembangan kurikulum itu sendiri. Untuk institusi pendidikan dokter, alumni dapat memberikan informasi mengenai kesesuaian kompetensi yang didapat selama pendidikan dengan yang dibutuhkan saat bekerja. Informasi tersebut dapat menjadi dasar institusi pendidikan dalam bidang pengembangan kurikulum dan proses pembelajaran.

FK UNAND sendiri telah berdiri sejak tahun 1955 termasuk salah satu fakultas kedokteran tertua di Indonesia telah menghasilkan ribuan dokter. Dokter yang merupakan alumni FK UNAND ini tersebar diberbagai wilayah Indonesia, mulai dari kota-kota besar hingga ke daerah terpencil pedesaan. Para lulusan FK UNAND ini bekerja pada berbagai jenis lapangan kerja, baik yang berhubungan langsung dengan bidang kesehatan (pelayanan kedokteran) maupun tidak langsung (farmasi, dan lainnya). ${ }^{(5)}$ Kegiatan Tracer Study dapat menjadi sarana penghubung antara institusi dengan alumni tentang orientasi lulusan ke depan.

Dalam pelaksanaan Tracer Study di FK UNAND, Kegiatan ini sudah pernah dilakukan sebelumnya pada waktu perencanaan implementasi Kurikulum Berbasis Kompetensi (KBK) dengan 

ANDALAS

metode pembelajaran Problem Based Learning (PBL) tahun 2003-2004. Untuk kelanjutannya, pada tahun 2008 Tracer Study dilaksanakan dengan ruang lingkup lulusan FK Unand.

\section{METODE}

Tracer Study merupakan studi evaluatif dengan menggunakan pendekatan kuantitatif deskriptif dan kualitatif. Tracer Study 2008 dilaksanakan sepanjang Maret - Desember 2008. Populasi penelitian tahun 2008 ini adalah seluruh alumni FK UNAND, sedangkan pengambilan sampelnya adalah dengan metode purposif random sampling. Tim Tracer Study 2008 bekerja mengumpulkan data-data dari alumni yang hadir pada berbagai kegiatan alumni dan seminar yang diadakan dilingkungan FK UNAND. Beberapa kegiatan pengumpulan data yang telah direncanakan seperti turun langsung kelapangan diberbagai daerah di Sumatera Barat dan dengan sistem korespondensi tidak dapat dilaksanakan karena keterbatasan waktu, biaya dan tenaga. Adapun kegiatan yang telah dilakukan dan mendapat edaran kuesioner adalah sebagai berikut :

a. Acara pertemuan alumni FK UNAND dalam rangka peringatan acara Dies Natalis UNAND tahun 2008. b. Acara pertemuan alumni angkatan 1983 yang diadakan di Hotel Nuansa Maninjau tanggal 4 Oktober 2008.

c. Acara pertemuan alumni angkatan 1986 yang diadakan di Hotel Nuansa Maninjau tanggal 5 Oktober 2008.

d. Seminar ilmiah KPPIK (Kursus Penyegaran dan Penambahan Ilmu Kedokteran) di Pangeran Beach Hotel Padang tanggal 18 Oktober 2008.

e. Acara Yudisium Dokter Baru periode Oktober 2008.

f. Acara wisuda Dokter periode Agustus 2008.

Pada tiap kegiatan tersebut, kuesioner disebarkan dan diisi secara langsung kepada alumni untuk diisi secara langsung. Kesulitan yang dialami oleh tim Tracer Study tahun 2008 adalah dari 800 kuesioner yang diedarkan, yang kembali hanya sebesar 124 kuesioner.

Penelitian Tracer Study ini dalam bentuk studi evaluatif dengan menggunakan kuesioner terstruktur sebagai instrumen penelitian dan ditambah dengan pertanyaan terbuka untuk mendapatkan informasi sebanyakbanyaknya. Kuesioner Tracer Study 2008 terdiri dari 7 tema dengan blueprint-nya sebagai berikut : 
Tabel 1. Blueprint kuesioner Tracer Study 2008

\begin{tabular}{lll}
\hline No & Tema & Kategori \\
\hline 1 & $\begin{array}{l}\text { Pelayanan } \\
\text { akademik }\end{array}$ & $\begin{array}{l}\text { Kepuasan terhadap pelayanan akademik } \\
\text { Pengalaman mengecewakan dengan pelayanan } \\
\text { akademik }\end{array}$ \\
2 & $\begin{array}{l}\text { Kegiatan } \\
\text { pendidikan }\end{array}$ & $\begin{array}{l}\text { Kepuasan saat pengikuti pendidikan pre klinik } \\
\text { Kepuasan saat mengikuti pendidikan klinik }\end{array}$ \\
3 & $\begin{array}{l}\text { Pencapaian } \\
\text { kompetensi }\end{array}$ & $\begin{array}{l}\text { Pencapaian kompetensi sebagai dokter umum } \\
\text { setelah menyelesaikan pendidikan } \\
4\end{array}$ \\
Usulan & Saran untuk perbaikan proses pendidikan \\
\hline
\end{tabular}

\section{HASIL}

Penelitian ini berusaha melacak pendapat alumni fakultas kedokteran Universitas Andalas mengenai aspek pelayanan akademik, sistem pendidikan preklinik, sistem pendidikan klinik, dan kompetensi klinis lulusan sebagai dokter umum. Jumlah kuesioner yang dikembalikan sebanyak 124 kuesioner dari 800 kuesioner yang disebar. Rendahnya jumlah kuesioner yang dapat diolah disebabkan beberapa faktor. Yang pertama, adanya pengisian ganda oleh responden. Kuesioner disebar pada beberapa seminar yang dihadiri oleh peserta yang sama. Kedua, pengisian kuesioner oleh mahasiswa dan bukan alumni Fakultas Kedokteran Universitas Andalas. Responden dikelompokkan menjadi empat kelompok menurut tahun masuk (angkatan) mereka di fakultas kedokteran. Responden dengan tahun masuk paling dini berasal dari tahun masuk 1986 dan paling akhir adalah dari tahun masuk 2002. Semua responden ini menempuh berikut ini : sistem pendidikan konvensional yang bersifat teacher-centered learning. Hasil tersebut ditabulasi dan diolah secara statistik sehingga data tersebut dapat dibaca.

Penelitian ini melibatkan sebanyak total 124 orang responden yang dikelompokkan menurut tahun masuk di fakultas kedokteran Universitas Andalas (angkatan). Responden terdiri atas 87 wanita dan 37 pria. Dari hasil pengelompokan diperoleh bahwa responden berasal dari tahun masuk 1986 sampai 2002, dengan pengecualian tahun masuk 1993 karena tidak ada responden. Responden yang tidak menuliskan tahun masuk atau tahun masuk sebelum 1986 dikelompokkan tersendiri (kolom NA). Distribusi responden menurut tahun masuknya, responden terbanyak berasal dari tahun masuk 1996 sebanyak 14 orang (11,3\%) dan paling sedikit dari tahun masuk 1991 yaitu 1 orang $(0,8 \%)$. Untuk lebih jelasnya dapat dilihat pada grafik 


\section{Grafik 1. Distribusi Frekuensi Responden Berdasarkan Tahun Masuk}

\section{Responden}

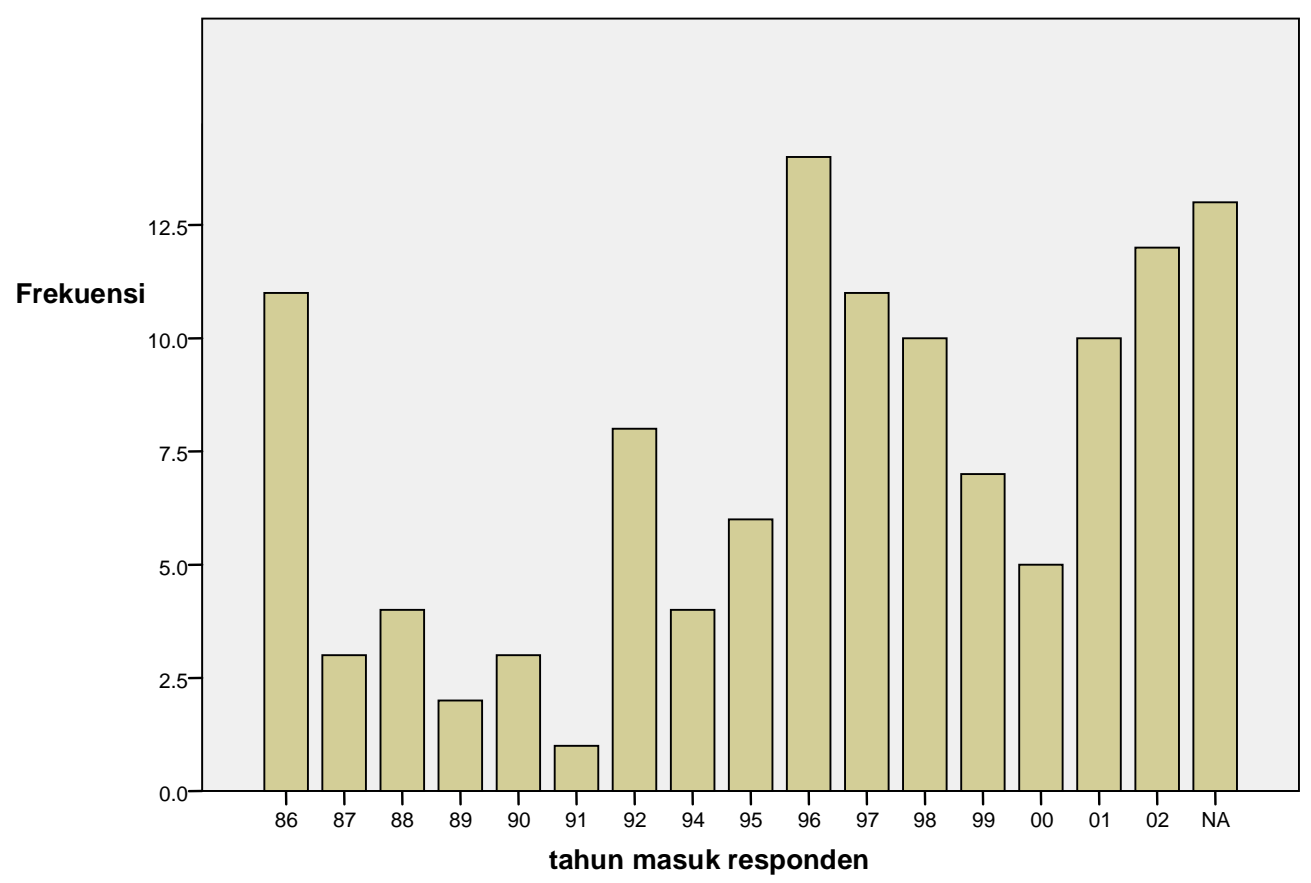

Pelayanan akademik merupakan faktor fakultas kedokteran Universitas yang berkaitan erat dengan kelancaran Andalas sedikit lebih banyak dari proses pendidikan dan menunjang jumlah responden yang merasa tidak keberhasilan studi mahasiswa. Dari puas (53 orang; 42,7\%), sisanya penelitian ini didapatkan bahwa jumlah sebanyak 5 orang $(4 \%)$ tidak menulisresponden yang merasa puas (66 orang; kan pendapatnya pada kuesioner. Hal $53,2 \%$ ) dengan pelayanan akademik di ini disajikan pada Tabel 2 berikut ini :

Tabel 2. Kepuasan responden terhadap pelayanan akademik berdasarkan tahun masuk responden

\begin{tabular}{rrrrr}
\hline & & \multicolumn{3}{c}{ Pelayanan Akademik } \\
\cline { 3 - 5 } & & Puas & Tidak Puas & Total \\
\hline tahun masuk responden & $1986-1991$ & 14 & 7 & 21 \\
& $1992-1997$ & 23 & 19 & 42 \\
& $1998-2002$ & 22 & 22 & 44 \\
& NA & 7 & 5 & 12 \\
\hline Jumlah Total & 66 & 53 & 119 \\
\hline Persentase & 55.5 & 44.5 & 100 \\
\hline
\end{tabular}


Kepuasan responden terhadap dengan sistem pendidikan preklinik dan sistem pendidikan preklinik disajikan hanya sebanyak 45 orang $(36,3 \%)$ yang pada Tabel 3 dan Grafik 1. Dari tabel tidak puas, sementara 6 orang $(4,8 \%)$ tampak bahwa sebagian besar respon- tidak mengisi poin ini pada kuesioner. den (73 orang; 58,9\%) menyatakan puas Tabel 3. Kepuasan responden terhadap sistem pendidikan
preklinik berdasarkan tahun masuk responden

\begin{tabular}{rrrrr}
\hline & & \multicolumn{3}{c}{ Sistem Pendidikan Preklinik } \\
\cline { 3 - 5 } & & Puas & Tidak Puas & Total \\
\hline tahun masuk responden & $1986-1991$ & 14 & 9 & 23 \\
& $1992-1997$ & 23 & 19 & 42 \\
& $1998-2002$ & 27 & 13 & 40 \\
& NA & 9 & 4 & 13 \\
\hline & Jumlah total & 73 & 45 & 118 \\
\hline Persentase & 61.9 & 38.1 & 100 \\
\hline
\end{tabular}

Sebanyak 61 responden $(49,2 \%)$ Tiga responden $(2,4 \%)$ tidak memberimenyatakan tidak puas terhadap sistem kan pendapatnya mengenai poin ini. pendidikan klinik, hal ini tidak jauh Kepuasan responden terhadap sistem berbeda dengan jumlah responden yang pendidikan klinik dapat dilihat pada puas yaitu sebanyak 60 orang $(48,4 \%)$. Tabel 4 .

Tabel 4. Kepuasan responden terhadap sistem pendidikan klinik menurut tahun masuk responden

\begin{tabular}{rrrrr}
\hline & & \multicolumn{3}{c}{ Sistem pendidikan klinik } \\
\cline { 3 - 5 } & & Puas & Tidak Puas & \multicolumn{1}{c}{ Total } \\
\hline tahun masuk responden & $1986-1991$ & 14 & 8 & 22 \\
& $1992-1997$ & 26 & 17 & 43 \\
& $1998-2002$ & 12 & 31 & 43 \\
& NA & 8 & 5 & 13 \\
\hline & Jumlah total & 60 & 61 & 121 \\
\hline persentase & $\mathbf{4 9 . 6}$ & $\mathbf{5 0 . 4}$ & $\mathbf{1 0 0}$ \\
\hline
\end{tabular}

Untuk melihat lebih jelasnya gambaran preklinik dan klinik secara keseluruhan tingkat kepuasan responden terhadap dapat dilihat pada grafik 2 berikut ini. pelayanan akdemik, sistem pendidikan 

ANDALAS

Grafik 2. Persentase tingkat kepuasan responden terhadap pelayanan akademik, sistem pendidikan preklinik dan sistem pendidikan klinik

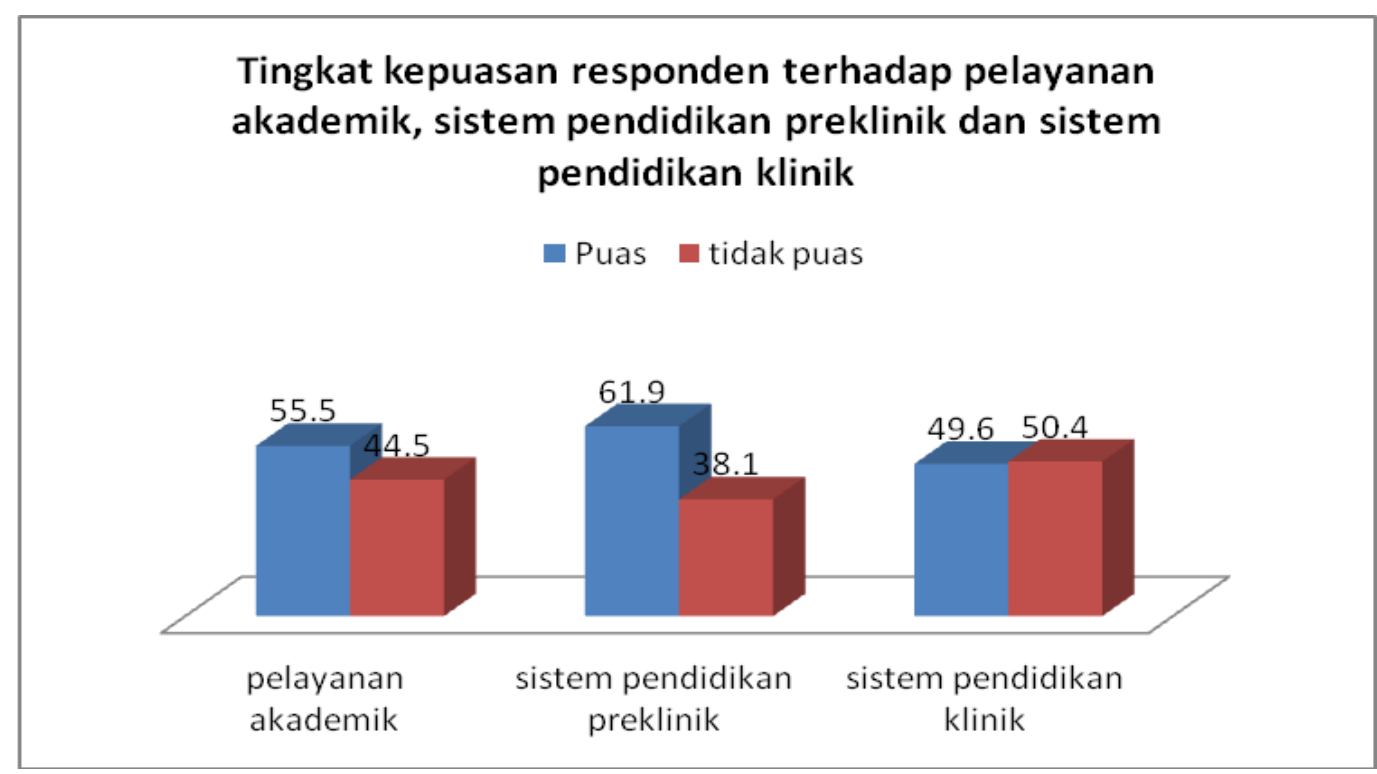

Untuk pertanyaan pencapaian kompe- sebagai dokter umum. Responden yang tensi saat setelah menyelesaikan pendi- merasa tidak kompeten setelah menadikan didapatkan hasil sebagian besar matkan studi sebanyak 40 orang responden (80 orang; 66,7\%) merasa (33,3\%), sedangkan sisanya 4 responcukup memiliki kompetensi klinis den tidak menjawab poin ini.

Tabel 5. Pendapat Responden Mengenai Kompetensi Klinisnya Setelah Menyelesaikan Pendidikan Dokter Umum

\begin{tabular}{ccrrr}
\hline & & \multicolumn{3}{c}{ Kompetensi klinik } \\
\cline { 3 - 5 } & & Kompeten & Tidak kompeten & Total \\
\hline tahun masuk & $1986-1991$ & 17 & 6 & 23 \\
responden & $1992-1997$ & 28 & 15 & 43 \\
& $1998-2002$ & 24 & 17 & 41 \\
& NA & 11 & 2 & 13 \\
\hline & Jumlah total & 80 & 40 & 120 \\
\hline & Persentase & $\mathbf{6 6 . 7}$ & $\mathbf{3 3 . 3}$ & $\mathbf{1 0 0}$ \\
\hline
\end{tabular}

Untuk melihat hubungan antara maka dilakukan uji Chi-Square karena kepuasan responden terhadap sistem ketiga variabel merupakan variabel pendidikan preklinik dan klinik dengan kategorikal. Kemaknaan statistik ditunpendapat responden mengenai kom- jukkan oleh nilai $\mathrm{P}<0,05$. Ternyata petensi klinisnya sebagai dokter umum terdapat hubungan yang bermakna 
secara statistik antara kepuasan terha- antara kepuasan terhadap sistem pendap sistem pendidikan preklinik dan didikan klinik dan persepsi tentang kompetensi klinis yang dimiliki res- kompetensi klinis $(\mathrm{P}<0,05)$.Uji Chiponden $(\mathrm{P}=0,007)$. Juga terdapat hubu- Square ini dapat dilihat pada Tabel 6.

ngan yang bermakna secara statistik

Tabel 6. Uji Chi-Square Untuk Variabel Sistem Pendidikan Preklinik dan Kompetensi Klinis

a. Tabel Silang

\begin{tabular}{cccc}
\hline & & \multicolumn{2}{c}{ Kompetensi Klinis } \\
\cline { 3 - 4 } & & Kompeten & Tidak Kompeten \\
\hline $\begin{array}{c}\text { sistem } \\
\text { pendidikan } \\
\text { preklinik }\end{array}$ & Ya & 53 & 17 \\
\hline & Tidak & 23 & 22 \\
\hline $\begin{array}{c}\text { sistem } \\
\text { pendidikan } \\
\text { klinik }\end{array}$ & Ya & 50 & 9 \\
\hline
\end{tabular}

b. Pearson Chi-Square Tests

\begin{tabular}{ccc}
\hline & & Kompetensi Klinis \\
\hline sistem pendidikan & Chi-square & 7.398 \\
preklinik & Df & 1 \\
& Sig. & $.007(*)$ \\
\hline \multicolumn{3}{c}{} \\
\hline sistem pendidikan & Chi-square & 17.675 \\
klinik & Df & 1 \\
& Sig. & $.000(*)$ \\
\hline The Chi-square statistic is significant at the 0.05 level.
\end{tabular}

Pada Tabel 7 disajikan uji Chi-Square klinik. Ternyata terdapat hubungan antara variabel kepuasan terhadap sis- yang bermakna secara statistik antara tem pendidikan preklinik dan variabel kedua variabel ini $(\mathrm{P}<0,05)$.

kepuasan terhadap sistem pendidikan 


\section{Tabel 7. Uji Chi-Square Variabel Sistem \\ Pendidikan Preklinik dan Sistem Pendidikan Klinik}

a. Tabel Silang

\begin{tabular}{|c|c|c|c|}
\hline \multirow{4}{*}{$\begin{array}{l}\text { sistem pendidikan } \\
\text { klinik }\end{array}$} & \multirow[b]{3}{*}{$\mathrm{Ya}$} & \multicolumn{2}{|c|}{$\begin{array}{c}\text { Sistem Pendidikan } \\
\text { Preklinik }\end{array}$} \\
\hline & & $\mathbf{Y a}$ & Tidak \\
\hline & & 49 & 9 \\
\hline & Tidak & 23 & 35 \\
\hline
\end{tabular}

b. Pearson Chi-Square Tests

\begin{tabular}{llr}
\hline & & Sistem Pendidikan Preklinik \\
\hline sistem pendidikan & Chi-square & 24.753 \\
klinik & Df & 1 \\
\hline & $*$ & The Chi-square statistic is significant at the 0.05 level.
\end{tabular}

Uji Chi-Square dilakukan untuk makna secara statistik antara tahun melihat hubungan antara tahun masuk masuk responden dan pendapat responresponden dan pendapat responden den mengenai kompetensi klinisnya tentang kompetensi klinisnya sebagai $(\mathrm{P}<0,05)$. Uji ini disajikan pada Tabel 8 dokter umum. Dari hasil uji diperoleh di bawah ini.

bahwa terdapat hubungan yang ber-

\section{Tabel 8. Uji Chi-Square Untuk Variabel Tahun Masuk Responden dan Kompetensi Klinis}

\section{a. Tahun masuk responden}

\begin{tabular}{cccc}
\hline $\begin{array}{c}\text { Tahun masuk } \\
\text { FK }\end{array}$ & Observed N & Expected N & Residual \\
\hline 86 & 11 & 7.3 & 3.7 \\
87 & 3 & 7.3 & -4.3 \\
88 & 4 & 7.3 & -3.3 \\
89 & 2 & 7.3 & -5.3 \\
90 & 3 & 7.3 & -4.3 \\
91 & 1 & 7.3 & -6.3 \\
92 & 8 & 7.3 & .7 \\
94 & 4 & 7.3 & -3.3 \\
95 & 6 & 7.3 & -1.3 \\
96 & 14 & 7.3 & 6.7 \\
97 & 11 & 7.3 & 3.7 \\
98 & 10 & 7.3 & 2.7 \\
\hline
\end{tabular}




\begin{tabular}{cccc}
\hline 99 & 7 & 7.3 & -.3 \\
00 & 5 & 7.3 & -2.3 \\
01 & 10 & 7.3 & 2.7 \\
02 & 12 & 7.3 & 4.7 \\
NA & 13 & 7.3 & 5.7 \\
Total & 124 & & \\
\hline
\end{tabular}

b. Kompetensi Klinis

\begin{tabular}{lrrr}
\hline Penilaian kompetensi & Observed N & Expected N & Residual \\
\hline kompeten & 80 & 60.0 & 20.0 \\
tidak kompeten & 40 & 60.0 & -20.0 \\
Total & 120 & & \\
\hline
\end{tabular}

c. Test Statistics

\begin{tabular}{lrr}
\hline & $\begin{array}{c}\text { Tahun Masuk } \\
\text { Responden }\end{array}$ & \multicolumn{2}{c}{ Kompetensi } \\
& Klinis \\
\hline Chi-Square(a,b) & 37.774 & 13.333 \\
df & 16 & 1 \\
Asymp. Sig. & .002 & .000 \\
\hline
\end{tabular}

a 0 cells $(.0 \%)$ have expected frequencies less than 5 . The minimum expected cell frequency is 7.3 .

b 0 cells $(.0 \%)$ have expected frequencies less than 5 . The minimum expected cell frequency is 60.0 .

Uji Chi-Square pada Tabel 9 di bawah menunjukkan adanya hubungan yang ini menyajikan hubungan antara jenis bermakna secara statistik antara jenis kelamin responden dan persepsi respon- kelamin responden dan persepsi responden tentang kompetensi klinisnya. Dari den tentang kompetensi klinisnya. hasil uji diperoleh nilai $\mathrm{P}<0,05$ yang

Tabel 9. Hubungan jenis kelamin reponden dan persepsi responden tentang kompetensi klinisnya.

a. Tabel Silang

\begin{tabular}{lrrrr}
\hline & & \multicolumn{3}{c}{ Kompetensi Klinis } \\
\cline { 3 - 5 } & & Kompeten & $\begin{array}{c}\text { Tidak } \\
\text { Kompeten }\end{array}$ & Total \\
\cline { 3 - 6 } & & Count & Count & Count \\
\hline $\begin{array}{l}\text { jenis kelamin } \\
\text { responden }\end{array}$ & pria & 31 & 6 & 37 \\
& wanita & 49 & 34 & 83 \\
\hline
\end{tabular}




\section{b. Pearson Chi-Square Tests}

\begin{tabular}{llr} 
& & Kompetensi Klinis \\
\hline $\begin{array}{l}\text { jenis kelamin } \\
\text { responden }\end{array}$ & Chi-square & 7.053 \\
& & 1 \\
& Df & $.008(*)$ \\
\hline
\end{tabular}

Results are based on nonempty rows and columns in each innermost subtable.

* The Chi-square statistic is significant at the 0.05 level.

DISKUSI

Penelitian ini berusaha melacak pendapat alumni fakultas kedokteran Universitas Andalas mengenai aspek pelayanan akademik, sistem pendidikan preklinik, sistem pendidikan klinik, dan kompetensi klinis lulusan sebagai dokter umum.

Pada tracer sstudy 2008 diperoleh 124 kuesioner dari 800 kuesioner yang disebar. Rendahnya jumlah kuesioner yang dapat diolah disebabkan beberapa faktor. Yang pertama, adanya pengisian ganda oleh responden. Kuesioner disebar pada beberapa seminar yang dihadiri oleh peserta yang sama. Kedua, pengisian kuesioner oleh mahasiswa dan bukan alumni Fakultas Kedokteran Universitas Andalas. Responden dikelompokkan menjadi 4 kelompok menurut distribusi frekuensi tahun masuk (angkatan) mereka di fakultas kedokteran. Responden dengan tahun masuk paling dini berasal dari tahun masuk 1986 dan paling akhir adalah dari tahun masuk 2002. Semua responden ini menempuh sistem pendidikan konvensional yang bersifat teacher-centered learning.
Untuk pelayanan akademik, lebih dari setengah responden merasa puas. Namun 44,5\% yang merupakan persentase yang cukup besar untuk ketidak puasan responden terhadap pelayanan akademik. Menurut uraian jawaban responden, faktor-faktor yang menentukan kepuasan terhadap pelayanan akademik antara lain keramahan, kesediaan membantu, keakuratan dan kecekatan petugas dalam membantu mahasiswa mengurus kartu rencana studi, memeriksa nilai mata kuliah, pengurusan ujian, pendaftaran ulang dan pengurusan yudisium atau wisuda. Adanya pelayanan yang lambat atau kurang bersahabat serta entri data yang tidak akurat merupakan penyebab sebagian besar ketidakpuasan yang diutarakan responden.

Hal khusus yang menjadi catatan untuk pelayanan akademik adalah banyaknya responden yang kecewa karena pengumuman nilai siklus klinik yang sering terlambat sehingga merugikan mahasiswa yang gagal yang seharusnya dapat mengurus perbaikan nilai pada siklus berikutnya. Pemanfaatan teknologi informasi seperti sistem nilai secara komputerisasi seharusnya 
memungkinkan sistem rekapitulasi nilai mahasiswa di klinik lebih cepat. Selain itu perlunya optimalisasi kemampuan staf kependidikan FK Unand dibidang teknologi informasi.

Steinert dalam tulisannya menyebutkan bahwa fungsi staf kependidikan didesain untuk dapat meningkatkan efektifitas kegiatan belajar mengajar disemua level pendidikan secara berkelanjutan. ${ }^{(1)}$ Oleh karena itu perlu program pengembangan lebih lajut dibidang sumber daya manusia di FK Unand, yang tidak hanya untuk staf pendidik, namun juga untuk staf kependidikan. Pengembangan kemampuan staf kependidikan tidak hanya dibidang yang terkait dengan tugas pokok mereka, namun juga dibidang softskills. Selain pengembangan kemampuan staf kependidikan, dibutuhkan juga disusun Standar Operating Procedure (SOP) untuk pelayanan akademik di klinik.

Untuk sistem pendidikan preklinik, sebagian besar responden merasa puas dengan sistem yang mereka jalani. Responden yang menyatakan tidak puas terutama mengenai bahan perkuliahan yang tidak menyajikan perkembangan ilmu terkini, cara penyampaian materi perkuliahan yang tidak variatif, dan banyaknya mahasiswa dalam satu kelas yang membuat proses belajar-mengajar menjadi tidak kondusif.

Amin dan Ko $(2003)^{(6)}$ dalam bukunya menjelaskan bahwa kegiatan perkuliahan merupakan salah satu cara proses pembelajaran yang umum digunakan institusi pendidikan dokter. Manfaat dari perkuliahan ini adalah dapat berikan materi ilmu secara menyeluruh, diikuti oleh banyak mahasiswa, hanya membutuhkan waktu dan sarana yang minimun, terstruktur dan koheren, serta dibawah kekuasaan dan kontrol dari dosen. Namun kuliah dalam kelas besar juga memiliki keterbatasan seperti mahasiswa berada pada posisi yang inaktif dan pasif. Dosen berperan sebagai aktor yang melakukan dialog monolog. Jika seorang penampilan seorang bagus, maka mahasiswa akan memberikan perhatian dengan cara mendengar, namun jarang memberikan pertanyaan. Selain itu dari segi pemahaman dan ingatan terhadap topik perkuliahan, hanya bertahan sebentar di ingatan mahasiswa.

Keputusan FK Unand pada tahun 2004 untuk beralih ke sistem student centered learning dengan menggunakan kurikulum berbasis kompetensi seperti yang telah ditetapkan oleh KKI dalam buku Standar Kompetensi Dokter ${ }^{(2)}$ adalah untuk mengurangi keterbatasan tersebut. Dalam SCL, mahasiswa dituntut untuk aktif dalam proses pembelajaran dan banyak berintraksi dengan dosen. Strategi pembelajaran yang digunakan di FK Unand adalah Problem Based Learning (PBL). PBL merupakan salah satu strategi pembelajaran yang bersifat interaktif dan banyak pihak yang mengklaim bahwa strategi ini lebih efektif dibandingkan metode tradisional untuk pengembangan kemampuan dalam belajar sepanjang hayat. ${ }^{(7,8)}$ Hasil dari tracer study ini dapat memperkuat alasan FK Unand untuk menggunakan sistem SCL dengan strategi pembelajaran PBL. 
Dari respoden juga didapatkan salah satu penyebab ketidak puasan terhadap pendidikan preklinik adalah segi standar kelulusan yang dianggap sulit. Morrison (2003) dan Vleuten (2000) dalam tulisannya tentang sistem evaluasi/Assessment, menyebutkan bahwa karakteristik dari suatu sistem evaluasi adalah reliabilitas, validitas, akseptablitas dan tidak mahal. Lebih lanjut dijelaskan bahwa mahasiswa membutuhkan kejelasan hasil evaluasi belajar mereka sebagai bentuk umpan balik dari hasil belajar mereka. ${ }^{(9,10)}$ Dalam penelitian ini didapatkan responden mengharapkan bahwa standar hasil evaluasi belajar mereka harus lebih diperjelas sehingga mereka bisa mengetahui sampai dimana kemampuan atau hasil belajar mereka.

Usulan untuk perbaikan pendidikan di preklinik adalah sebagian responden menganggap waktu yang dialokasikan untuk praktikum terlalu singkat, sehingga sebaiknya ditambah. Selain itu untuk mempersingkat masa studi preklinik, responden menyarankan/mendukung adanya semester pendek. Responden berharap agar mata kuliah yang diajarkan di preklinik adalah yang benar-benar relevan dengan peran nantinya sebagai dokter umum dan

mereka mengharapkan agar dosen yang mengampu mata kuliah memiliki kompetensi yang memadai.

Mengenai sistem pendidikan klinik, jumlah responden yang tidak puas hampir sama banyak dengan responden yang puas. Hal yang menarik dari jawaban responden, sebagian besar yang tidak puas mengeluhkan sistem penilaian yang sangat subjektif. Padahal dalam berbagai teori tentang student assessment menyebutkan bahwa "assessment drive student's learning", evaluasi dapat meningkatkan proses pembelajaran mahasiswa. ${ }^{(1,6,10)}$ Penilaian yang subjektifitas dapat menurunkan semangat mahasiswa dalam belajar. Oleh karena itu perlu disusun suatu alat uji yang bisa menguji mahasiswa secara objektif sehingga sistem evaluasi tersebut juga dapat memberikan umpan balik untuk mahasiswa itu sendiri.

Responden yang merasa puas dengan sistem pendidikan klinik terutama berasal dari tahun masuk sebelum tahun 1998. Dari uraian jawaban responden, faktor yang mendorong kepuasan dalam pendidikan klinik adalah banyaknya interaksi dosen dan residen dengan mahasiswa serta kesempatan menangani banyak kasus penyakit, termasuk melakukan tindakan medis di bawah pengawasan dosen atau residen. Spencer (2003) menyebutkan experiential learning (belajar berdasarkan pengalaman) merupakan bagian dari pendidikan di klinik. ${ }^{(11)}$ Pada mahasiswa angkatan sebelum 1998, jumlah mahasiswa yang masih sedikit sebanding dengan jumlah staf pendidik dan pasien.

Responden dari tahun masuk 1998-2002 sebagian besar tidak puas dengan sistem pendidikan klinik yang mereka jalani. Faktor yang menyebabkan ketidakpuasan adalah jumlah mahasiswa yang terlalu banyak dalam satu siklus sehingga tidak sesuai dengan kapasitas ruangan di klinik dan terbatasnya waktu staf pengajar untuk 
melakukan bed-side teaching. Selain itu, banyaknya mahasiswa juga mengurangi peluang interaksi dengan lebih banyak pasien. Hal-hal ini sesuai dengan yang disebutkan Spencer $(2003)^{(11)}$ dalam tulisannya tentang tantangan dalam pelaksanaan pendidikan di klinik. Tantangan tersebut adalah keterbatasan waktu dan banyaknya tuntutan tugas staf pendidik klinik seperti dalam mengajar, pelayanan, penelitian dan administrasi. Selain itu jumlah mahasiswa yang semakin meningkat dan jumlah pasien untuk dipelajari semakin berkurang. Penyebab berkurangnya pasien adalah semakin pendeknya lama rawat inap, keadaan pasien terlalu parah atau gawat dan pasien menolak diperiksa mahasiswa. Pemecahan permasalahan ini sebenarnya sudah dilakukan oleh FK Unand dengan cara menambah jumlah staf pendidik dan memperbanyak rumah sakit jejaring.

Beberapa responden juga mengeluhkan pengaturan siklus dengan urutan yang tidak logis, seperti menempatkan siklus Community Oriented Medical Education (COME) sebagai siklus pertama. COME merupakan kegiatan pembelajaran di klinik yang komprehensif, dimana melibatkan mahasiswa secara langsung turun ke lapangan dalam hal kegiatan promotif, preventif dan kuratif di bidang pelayanan kesehatan. Untuk itu seorang mahasiswa harus mempunyai bekal yang cukup dalam hal ini sudah mengikuti semua siklus di pendidikan klinik sebelum mengikuti COME.

Saran yang diajukan responden untuk peningkatan mutu sistem pendidikan klinik antara lain dilengkapinya sarana dan prasarana pembelajaran mahasiswa klinik, dikuranginya penerimaan mahasiswa dari luar negeri atau program non-reguler melalui seleksi masuk yang lebih ketat, kerjasama dengan lebih banyak rumah sakit jejaring, penambahan jumlah staf pengajar klinis serta pengaturan jadwal kegiatan klinis yang jelas.

Dalam hal persepsi kompetensi klinis sebagai dokter umum, sebagian besar responden $(64,5 \%)$ berpendapat mereka telah kompeten sebagai dokter umum setelah menyelesaikan pendidikan. (Tabel 5). Hal ini didasarkan pada kemampuan mereka menangani kasuskasus sewaktu bertugas di rumah sakit atau puskesmas yang tidak terlepas dari pengalaman menghadapi kasus sewaktu pendidikan klinik. Responden yang merasa tidak kompeten beralasan minimnya kasus yang dihadapi, minimnya bimbingan langsung dari staf pengajar, dan kurangnya kesempatan melakukan tindakan medis selama pendidikan. Selain itu mereka menyatakan tidak memperoleh kemampuan manajerial untuk menjadi pimpinan puskesmas atau posisi struktural lainnya.

Pada analisis bivariat, adanya hubungan yang bermakna secara statistik antara variabel kepuasan terhadap sistem pendidikan preklinik maupun sistem pendidikan klinik dengan persepsi responden atas kompetensi klinisnya sudah dapat diduga. Hal ini disebabkan peran kedua komponen tersebut dalam membentuk kompetensi klinis. Namun belum ada data penelitian lain yang dapat menjadi pembanding 
hasil ini. Jika dilihat secara kese- sejauh mana pengaruh variabel tingkat luruhan, tingkat kepuasan selama kepuasan terhadap pendidikan ditahap menempuh pendidikan dokter akan preklinik dan klinik terhadap kommempengaruhi kepercayaan diri seo- petensi. Selain itu juga perlu digali rang dokter setelah menyelesaikan lebih dalam sejauh mana pengaruh pendidikannya. Hal yang menarik, ter- gender dan tahun masuk di fakultas nyata terdapat hubungan yang ber- terhadap kompetensi lulusan FK Unand. makna secara statistik antara jenis kelamin maupun tahun masuk responden dan persepsi responden tentang kompetensi klinisnya. Responden pria sebagian besar merasa kompeten setelah menyelesaikan pendidikan dan tidak demikian dengan responden wanita. Perlu dilakukannya penelitian lebih lanjut hubungan antara gender dengan kepercayaan diri seorang dokter.

\section{Kesimpulan}

Berdasarkan survei yang
telah dilakukan pada tahun 2008 terhadap 124 orang alumni fakultas kedokteran Universitas Andalas, dapat ditarik beberapa kesimpulan yaitu separuh responden tidak puas dengan pelayanan akademik dan pendidikan klinik. Sebagian besar respoden cukup puas dengan sistem pendidikan klinik. Lebih dari setengah responden merasa cukup memiliki kompetensi klinis sebagai dokter umum setelah menyelesaikan pendidikan di FK UNAND. Terdapat hubungan yang bermakna antara kepuasan responden terhadap sistem pendidikan klinik dan pendapatnya tentang kompetensi klinik sebagai dokter. Selain itu jumlah responden laki-laki yang merasa memiliki kompetensi klinis lebih banyak dari perempuan. Diperlukan penelitian lebih lanjut untuk melihat

\section{KEPUSTAKAAN}

1. Dent, J \& Harden, RM (2005). A practical guide for medical teacher. Elsevier limited.

2. KKI (Konsil Kedokteran Indonesia). 2006. Standar Kompetensi Dokter Indonesia; KKI, 2006.

3. KKI (Konsil Kedokteran Indonesia). 2006. Standar Profesi Pendidikan DOkter Indonesia. KKI. 2006.

4. FK Unand (Fakultas Kedokteran Universitas Andalas). 2006. Rencana Strategis Fakultas Kedokteran Universitas Andalas 2007-2011. FK Unand. 2006.

5. FK Unand (Fakultas Kedokteran Universitas Andalas).2004. Sejarah 50 tahun berdirinya FK Unand; FK Unand. 2004.

6. Amin Z, Khoo HE.2003. Basics in Medical Education. World Scientific Publishing Co.Pte. Ltd.

7. Smits PBA; Verbeek JHAM; Buisonje CDD. Problem based learning in continuing medical education: a review of controlled evaluation studies. BMJ Volume 32419 January 2002. bmj.com 
8. Iputo JE, Kwizera E. Problembased learning improves the academic performance of medical students in South Africa. Medical Education 2005; 39: $\quad 388-393 \quad$ Blackwell Publishing Ltd.

9. Morrison, J. $A B C$ of learning and teaching in medicine: Evaluation. bmj volume 326; 15 February 2003 bmj.com
10. Vleuten, CVD. Validity of final examinations in undergraduate medical training. BMJ Volume 321, 11 November 2000. bmj.com

11. Spencer, J. ABC of learning and teaching in medicine: Learning and teaching in the clinical environment. BMJ volume 326. 15 march 2003 bmj.com 